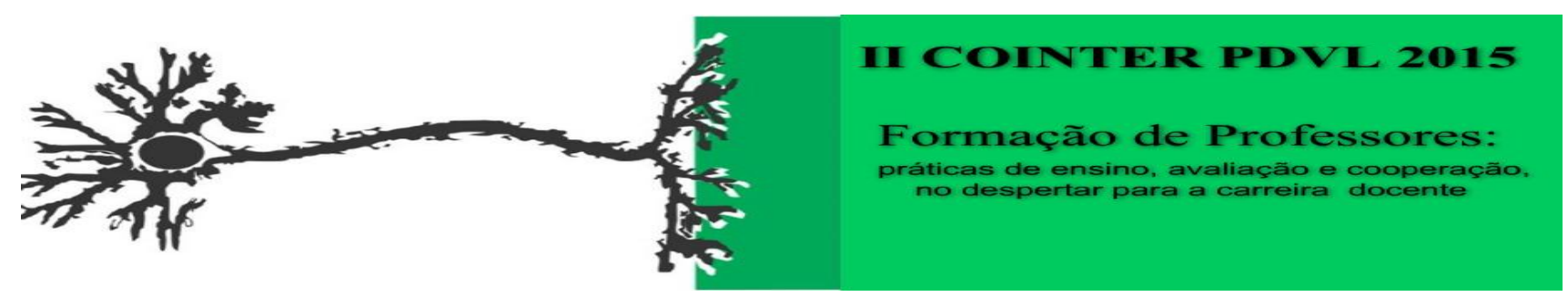

\title{
O USO DE MATERIAIS RECICLÁVEIS NO ENSINO DE GEOGRAFIA: ABORDAGEM SOBRE A PEDOGÊNESE E AS CARACTERÍSTICAS DO SOLO
}

\author{
Apresentação: Relato de Experiência \\ Paulo Sérgio Dantas da Silva ${ }^{1}$; Monik Maria da Conceição Lima²; Mádson Francisco da \\ Silva $^{3}$; Áurea Lucinda Monteiro ${ }^{4}$.
}

\section{Introdução}

A utilização de materiais recicláveis em prol do ensino de geografia a respeito da Pedogenese do Solo, foi aplicado no $9^{\circ}$ ano "A" do ensino fundamental da escola Estadual Dom Carlos Coelho, situada no município de Nazaré da Mata-PE, tendo por finalidade possibilitar uma aula prática a respeito das características dos solos, por meio da ludicidade. O objetivo da prática pedagógica foi vivenciar as propriedades físicas dos solos, que são a consistência, porosidade, granulometria, plasticidade e permeabilidade, transmitindo de forma prática e educativa, temas como conservação, manuseio sustentável, reconhecimento, reciclagem de materiais e a importância destes na abordagem prática a respeito do ensino de solos, onde serviu como ferramenta de testes a respeitos das propriedades do mesmo, ou seja, deu origem aos fundamentos práticos como ocorrem no meio natural, propondo um maior entendimento aos alunos do ensino fundamental sobre estes fenômenos.

\section{Relato de Experiência}

Solo é um corpo de material inconsolidado que cobre a superfície terrestre emersa entre a litosfera e a atmosfera. Sendo composto por minerais, matéria orgânica, ar e água, fundamental para alimentação dos seres vivos. No entanto, com as ações antrópicas sobre o meio, o solo vem sofrendo grandes impactos ambientais negativos, onde Favaretto \& Dieckon (2007, p. 121) ressaltam que: “Tradicionalmente, o solo foi considerado um recurso natural renovável. Mas, por causa da intensa degradação promovida nos últimos séculos, a disponibilidade do solo está sendo

\footnotetext{
${ }^{1}$ Graduando do Curso de Licenciatura em Geografia no Campus Mata Norte da Universidade de Pernambuco.

E-mail: paulo_dantas@outlook.com

${ }^{2}$ Graduanda do Curso de Licenciatura em Ciências Biológicas no Campus Mata Norte da Universidade de Pernambuco. E-mail: monikleonel@ hotmail.com

${ }^{3}$ Graduando do Curso de Licenciatura em Pedagogia no Campus Mata Norte da Universidade de Pernambuco.

E-mail: mamadson123@hotmail.com

${ }^{4}$ Orientadora, Professora Mestra dos Cursos de Lic. em Geografia e Ciências Biológicas no Campus Mata Norte-UPE.

E-mail: aureamonteiro@bol.com.br
} 
gravemente comprometida”. Assim, atualmente já não podemos mais considerar os Solos como recurso renovável.

Desse modo, resolvemos utilizar materiais recicláveis em prol de uma sensibilização ambiental a respeito das práticas degradantes do meio ambiente, na qual o ser humano está inserido, propondo o entendimento das características do Solo, através dos experimentos realizados com amostras de solos, garrafas pets, copos descartáveis, gases, tesoura, jornais e água.

A prática pedagógica tem inicio com uma introdução a respeito do que é o Solo e suas características no maio natural, qual a sua importância para os seres vivos e os impactos negativos causados pelos seres humanos neste recurso. Em seguida, é exposto a necessidade de reutilizar os resíduos sólidos descartados, visando a conservação ambiental deste e de outros recursos naturais, na qual a partir deste momento é notório a importância destes residuos em prol do ensino de geografia. No entanto, é feito os recortes nas garrafas pets, deixando um tipo de funil, tendo por finalidade pôr as amostras de solos, e, realizar testes sobre o tipo de solo mais permeável, poroso e impermeável. Além disso, são realizados testes a respeito da composição de ar no solo, onde é colocado um pouco de solo no copo, afim de que ao ser despejado a água o mesmo borbulhe comprovando a teórica, da mesma forma é feita com as garrafas, onde no tipo de solo (arenoso, argiloso, orgânico) em que a água infiltre primeiro e por ultimo, ficar mais úmido, comprovará determinados tipos de característica dos Solos.

\section{Considerações}

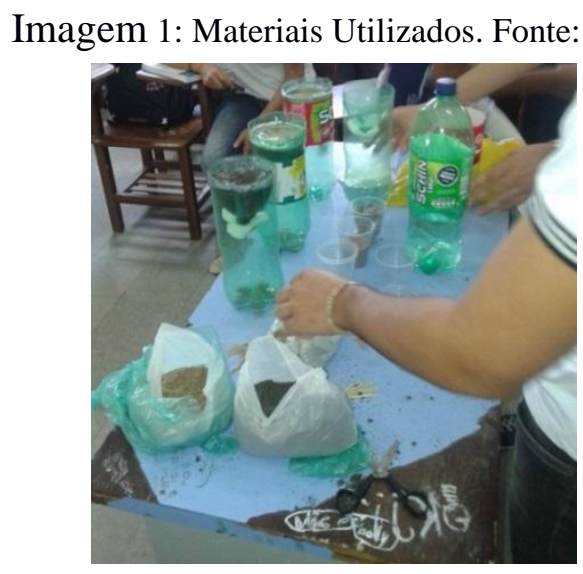

Portanto, através da utilização de materiais recicláveis em prol do ensino de geografia sobre o Solo, os alunos são sensibilizados a respeito da importância da conservação deste recurso como aponta Lepsch (2010). Além disso, estas ferramentas propõem a ludicidade e construção do conhecimento sobre solos de forma interativa, sendo de grande relevância para o entendimento dos discentes a respeito do Solo. 


\section{Referências}

LEPSCH, I. F. Formação e Conservação de Solos. São Paulo: Oficina de Textos, 2010.

FAVARETTO, N.; DIECKON, J. Conservação dos recursos naturais solo e água. In: LIMA, V. C.; LIMA, M. R.; MELO, V. F. (Eds.). O solo no meio ambiente: abordagem para professores do ensino fundamental e médio e alunos do ensino médio. Curitiba: UFPR, 2007. p. 111-126. 